\title{
BRAND PERSONALITY TOWARD CUSTOMER PURCHASE INTENTION: THE INTERMEDIATE ROLE OF ELECTRONIC WORD-OF-MOUTH AND BRAND EQUITY
}

\author{
Hojjat Vahdati ${ }^{1}$ and Seyed Hadi Mousavi Nejad ${ }^{*}$ \\ ${ }^{1,2}$ Department of Business Management, Lorestan University, Iran \\ *Corresponding author: Mousavi.Ha@fc.lu.ac.ir
}

Published online: 30 December 2016

To cite this article: Vahdati, H, Mousavi Nejad, S. H. (2016). Brand personality toward customer purchase intention: The intermediate role of electronic word-of-mouth and brand equity. Asian Academy of Management Journal, 21(2), 1-26. http://dx.doi.org/10.21315/ aamj2016.21.2.1

To link to this article: http://dx.doi.org/10.21315/aamj2016.21.2.1

\begin{abstract}
Organizations like banks with the ability to develop an understanding of and capability in predicting customer's behaviour are organisations that have an edge over their competitors in the marketplace. One way of how organization's competitive advantage can be achieved is when they can determine their customer's purchase intention of products. This study attempts to investigate if brand personality, e-WOM and brand equity are determining factors that influence bank's customers purchase intention which can lead to their purchase decision later. Here, Mellat Bank in Iran is used as a case study and the bank's customers participated as respondents in a survey. The study tested seven hypotheses using structural equation modeling techniques. The findings show that brand personality, e-WOM and brand equity have positive and significant effects on customer's purchase intentions. The results also reveal that these factors have positive internal effects on each other. In addition, e-WOM and brand equity show positive mediator roles.
\end{abstract}

Keywords: brand personality, electronic word-of-mouth, brand equity, customer purchase intention. 


\section{INTRODUCTION}

Cyberspace offered a new tool for marketers to improve the efficiency and effectiveness of marketing communications and new approaches to acquire and retain customers. One aspect of cyberspace is online interpersonal impacts. This issue in the online environment has influence on customers' evaluations and decisions about the purchase of a product or brand. Moreover, customer decisions for purchase and preference of a particular brand will need to review the existing brands in the market (Teng, Laroche \& Zhu, 2007). The importance of this issue is to the extent that today many world famous companies such as Procter \& Gamble and Mars are structured through their brands (Baker, Hunt \& Scribner, 2002), and exercise their power on purchase decisions and consumers tendency to pay the extra cost by brand (Aaker, 1991). Recently, useful constructs such as brand personality and brand equity entered into the brand literature (Aaker, 1997; Bouhlel, Mzoughi, Hadiji \& Ben Slimane, 2011), which considering them in the behavior intentions models in a broad range, could lead to non-price competitive advantage (Bouhlel et al., 2011; Bruwer \& Buller, 2005). This would increase the possibility of revealing the main factor and real cause of the purchase intentions leading to the purchase decision.

The present research is a case study of Mellat Bank in Iran. The good relationship with customers, providing suitable services as well as the frequent use of the brand by customers compared to the other banks are among those reasons to select Mellat Bank. These features may increase the possibility of attracting most of the statistical community through the brand and electronic word-of-mouth communication. However, Mellat bank is faced with serious problems due to its huge volume of television advertising. Heavy budgets of the public relation units and promotion plans of Mellat Bank are encountering with big challenges to the extent that they have led to the decline of market share and global ranking in Mellat bank. According to Banker Magazine in July 2012-2013, the global ranking of Mellat bank has been considerably reduced compared to the other banks. Therefore, it seems necessary for Mellat Bank to apply a distinctive strategy different from the other banks, spread a positive e-WOM and use the brand-oriented activities for maintaining the competition level in the financial market as well as to reduce the advertising costs, marketing budgets and increase the efficiency of programs and consumer intentions. 


\section{LITERATURE REVIEW}

\section{Purchase Intention}

One of the major concepts in marketing literature is purchase intention which has routine applications in researches and also covers wide range of products and services. Kim and Kim (2004) define purchase intention as the tendency of consumers with the identified aim where it is usually measured in terms of real purchasing. Moreover, Crosno, Freling \& Skinner (2009) described that purchase intention refers to the possibility of purchasing a special brand in a product category during purchase. However, the implementation of the product's purchase intention depends on various factors such as customer willingness and interest to the product, imposed social pressure on the customer from others and a general sense of what is received. These factors could be pursued according to the theory of reasoned action (TRA) and product evaluation model (PEM). TRA is proposed by Fishbein and Ajzen (1975) and is widely used in the consumer behavior literature and purchase intention studies (i.e. Botha \& Atkins, 2005; Beadnell, Baker, Gillmore, Morrison, Huang \& Stielstra, 2008; Alsughayir \& Albarq, 2013). This theory assumes an individual's intention to perform a behaviour as a function of 1 . his or her attitude towards that behaviour in a special situation; 2 . the norms governing the behaviour in such situation and the motivation to follow these norms (subjective norms). Since TRA is very instrumental and practical where the individual is personally responsible for his or her purchase intentions (Hakkak, Vahdati, \& Mousavi Nejad, 2015), it seems that it is a suitable framework to study the customers' purchase intentions in the bank.

However, some scholars such as Chung and Pysarchik (2000) believed that TRA may not be absolutely accurate and others such as Collen \& Hoekstra (2001) stated that the other external variables could be used to explain the purchase intention. One of these variables is the perceived value of customer which is clearly provided in PEM proposed by Dodds, Monroe and Grewal (1991) and has been recently noted as a constant factor in predicting the purchase intention (Chi, Yeh \& Tsai, 2011; Ainscough, Trocchia \& Gum, 2009). This model regards the purchase intention as a function of the perceived value and indicates that the customer's perception of quality and credibility initially influences on the perceived value and then, this perceived value affects on their evaluation of the purchase intention. It should be noted that if the customers do not maintain a good attitude toward the product or ignore the behavioral norms, then they will not have any tendency to purchase. Therefore, we tried to combine TRA and PEM to evaluate and predict the customers' intentions more accurately. Moreover, a range of attitude, subjective norms and perceived value are considered to evaluate the customers' intentions. 
As mentioned earlier, persuading customers to use the brand of bank is significant and could facilitate the maintenance and growth of market share of banks. In this regard, Bertoncelj and Moisescu (2010) points out that one way to persuade the customers and increase the market share is to create a powerful brand and reinforce it which would lead to establish long-term and interactive relationships among stakeholders and more importantly the customers. In addition, some researchers believe that focusing on some features of brand could be as an important factor in persuading the customers and success of organisations. Many factors are involved in the purchase intention of a customer and having them in mind could persuade the customer to use and buy the brand. They include brand personality (Aggarwal, 2004), brand equity (Aaker, 1991) and eWOM (Park \& Lee, 2009). Focusing on brand personality and brand equity creates a close relationship between the brand and the customer and will lead to the selection of the brand by making a good image of the bank and its services in the mind of consumers. Also, in today's technological age, customers have more interactions with each other and convey their purchase information which influence on their brand purchase decisions. Therefore, it seems that eWOM is also an effective factor to persuade a customer other than using different options of applying brand by marketers.

Accordingly, this research will investigate the effect of the above variables on customers' purchase intention. It studies this issue in the target community in order to become more familiar with the way customers are persuaded and their purchase intentions are changed. Then, this research will identify the most important factor for increasing the purchase intention of the customers among eWOM, brand personality and brand equity. In the following sections, these effective factors on the purchase intention of the customer are introduced and studied.

\section{Brand Personality}

Brand personality is instrumental for consumers and marketing, because it can create a procedure to differentiate among various brands and is a key determinant for consumer purchase intention (Bruwer \& Buller, 2005). In fact, when it is difficult to assess the product's features, consumers usually trust in brand personality. Aaker (1997) noted that brand personality is a set of human characteristics which consumers ascribe to brands. She proposed a five-dimensional model for brand personality which consists of 24 features and five dimensions including sincerity, excitement, competence, sophistication and ruggedness. This model is regarded as one of the most widely used instruments for measuring brand personality in different industries, while other models such as Braunstein and Ross (2010) model is applicable in only one particular industry. Brand sincerity within the framework provided by Aker means integrity and reality of a brand; brand excitement refers 
to how exciting and adventurous is a brand and a brand will deserve perception when it is sustainable and smart; brand sophistication also refers to the attraction and elegance of the brand and brand ruggedness refers to resistency and power of the brand.

In spite of criticisms towards Aaker's brand personality scale, for example Azoulay and Kapferer (2003) stated that Aaker scale is indicative of a mixture of some brand identity dimensions rather than a measure for brand personality; however, one can say that this model is appropriate in the process of reviewing and improving customer preferences in the purchase process through consistency and congruence between the brand and customer's personalities. Regarding this fact and since there are numerous studies which implemented Aaker's model, it is applied to examine the brand personality of Mellat Bank in this research.

Many factors are effective in the customers' intentions and their moods, however, brand personality is the first factor that should be considered by researchers. Brand personality is useful for marketers and customers, because it can establish a link with the customer (Temporal, 2000) and create a mechanism to be distinctive among brands; it also acts as a determinant key for customers' intentions (Bruwer \& Buller, 2005). As Aaker (1997) also indicated, brand personality is a main variable in consumers' purchase decisions and is an important concept in brand distinction which has a significant effect on the consumers' purchase decisions. In creating a brand personality, the most important factor probably is a close relationship between brand personality and consumer personality. However, when brand personality is in accordance with the consumer's desire, then consumer's intention and loyalty for buying brand will increase. Mengxia (2007) found out that brand personality affects on the customer preferences, loyalty and purchase intention. He used a comparative approach using 230 Chinese customers' ideas about two brands (Nike and Sony) and demonstrated that brand personality has a positive and significant effect on the purchase intention. Moreover, recent researches confirmed the significant effect of brand personality on the purchase intention (i.e. Wang, Yang \& Liu, 2009; Akin, 2011; Toldos-Romero \& OrozcoGómez, 2015). For example, Akin (2011) in a study entitled "Predicting Consumers' Behavioral Intentions with Perceptions of Brand Personality: A Study in Cell Phone Markets" explained that brand personality dimensions of competence, excitement, traditionalism and masculinity have significant and direct effects on consumers' behavioral intention, and the effects of competence and excitement are more than the other two dimensions. Finally, the findings of Toldos-Romero and Orozco-Gómez (2015) which focused on 400 undergraduates' students in Mexico using questionnaires between two groups of users and non-users of brand and multiple regression analysis revealed that brand personality and its dimensions are 
significant predictors for purchase intention and brand personality effect is higher among the users of the brand compared to the non-users. Hence, although many factors influence on the consumer intentions and conditions, brand personality is the first factor that should be considered by researchers.

\section{H1: Brand personality has a positive and significant effect on customer's purchase intention.}

\section{Brand Equity}

Brand equity which has become an important concept in marketing since 1980; is the added value created by the brand name for the organisation. At present, brand equity is one of the most important marketing variables which is widely discussed by researchers and marketing experts. The main reason for this reputation is the strategic role of brand equity in management decisions and creation of a competitive advantage for organizations (Atilgan, Aksoy \& Akinci, 2007). Brand equity construct can be surveyed according to three approaches: financial, corporate, and customer. In financial approach, brand equity is an increasing cash flow which is obtained via the nominated products in addition to the cash flows derived of selling nameless products. In corporate-based approach, brand equity is the value added to the company for the brand name and this revenue will not cover the same nameless product (Keller \& Lehmann, 2004). Finally, customer-based brand equity (CBBE) according to Keller (1993) is the effect of distinctive marketing of brand knowledge on consumer response lies in the brand marketing and increases the level of the brand which is familiar for the customer. As this study seeks to review the reaction of customers and their intention to use Mellat Bank's brand, this approach seems appropriate.

According to Aaker (1996. p. 7), brand equity is a "collection of assets and liabilities linked to brand name which added (or subtracted) to value provided by a product or service to the company or their customers. Lemon, Rust and Zeithaml (2001) have provided a more accurate definition of this concept: brand equity is subjective and intangible evaluation of brand beyond what customer acquire via objective assessment. Despite different definitions of brand equity, Keller and Aaker declare that brand equity generally consists of various dimensions that make up the foundation of value provided to the consumers. Keller (1993) in his study discusses that creating a strong brand equity is a gradual and staging process which is similar to a ladder. Aaker (1991) also believed that brand equity is a multidimensional construct and includes attitudinal and behavioural dimensions such as brand awareness, brand associations, perceived quality, other brand proprietary assets (attitudinal dimensions) and brand loyalty (behavioral dimension) where brand 
loyalty is a main dimension of brand equity. Due to the wide use of Aaker's model in numerous researches focusing on consumer perceptions (i.e. Yoo, Donthu \& Lee, 2000; Chang \& Liu, 2009; Jalilvand, Samiei \& Mahdavinia, 2012), this model is also used here to measure CBBE.

To stress on the effect of brand equity effect on purchase intentions, Aaker (1991) states that these two structures are in relationship with each other and when a product has a high brand equity, consumers tend to buy that product with a higher price or frequently; this fact indicates the positive relationship between brand equity and purchase intentions. He also believes that perceived quality can demonstrate outstanding differences of a product or service and be a reason for customers to select a brand. If the customer's perception towards the quality of a brand quality is high, then his or her intention to its purchase will be high. Moreover, Chi et al. (2011) pointed out that when a product has a known brand, the product can increase the probability of being selected by the customers and their purchase intention; thus, businesses should create a brand and promote its equity through marketing activities. Researchers such as Jung and Sung (2008) and Irshad (2012) showed that the more brand equity increases, the more consumer's preferences and loyalty to brand will increase. Jung and Sung in a cross-cultural study examined the customer-based brand equity among three groups of consumers in both America and Korea. Their findings showed that in addition to positive and significant relationship between brand equity and purchase intention in all groups of consumers, brand loyalty is the most important dimension in brand equity and has a positive relationship with purchase intention in three groups. Irshad also studied the relationship between brand equity and its dimensions with customers purchase intention. In this study, the perceived quality, brand associations/awareness and brand loyalty are considered as dimensions of customer-based brand equity and the results showed that these dimensions have positive and significant effects on customers' purchase intentions. Empirical evidence also shows that brand equity has a positive effect on consumer preferences, purchase intentions and brand choice (Chang \& Liu, 2009; Irshad, 2012).

H2: Brand equity has a positive and significant effect on customer's purchase intention.

In previous researches, the concept of brand personality and brand equity were related to each other, but it is believed that the brand personality is one of the fundamental elements to brand image that can help to create the brand equity (Aaker, 1996; Keller, 1993). Consumers can use the brand personality characteristics as the determinant factors of brand equity. Rekom, Jacobs and Verlegh (2006) believed that when customers know the product quality self-right and competitors 
can easily copy the product features, the strong brand identity and personality can be high valuable in shaping of brand equity. In fact, a unique brand personality can help to create an ideal and unique set of links in the customers' mind that leads to brand equity (Keller, 1993). Hence, brand personality and brand equity can help the brand equity and goes to a positive evaluation of the brand by consumer (Aaker, 1991).

As mentioned, brand personality increases the consumer's intention and interest as well as the level of their trust and loyalty (Aaker, 1997), and this is while brand loyalty which is an aspect of brand equity has been greatly affected by brand personality and brand preferences (Kim, Magnini \& Singal, 2011; Valette-Florence, Guizani \& Merunka, 2011). Some studies confirm the positive effect of brand personality on the brand equity (Stephanie, Aaron, Lay Peng \& Jayne, 2011; Gonçalves Santos, 2013; Hakkak et al, 2015). Stephanie et al. (2011) in a study entitled "The Effect of Brand Personality and Congruity on Customer-based Brand Equity and Loyalty of Personal Computer Brands", confirmed the effect of brand personality on brand equity and showed that the emotional dimensions and competence in the brands of personal computers are very important. Moreover, Gonçalves Santos (2013) in his study entitled "Axe's Brand Personality and Equity, consumers' perspectives on the brand's personality and equity" showed that the characteristics of the brand personality have significant effects on customer-based brand equity, so that the dimensions of excitement, competence and sophistication have significant and positive correlation with the dimensions of perceived quality and brand awareness, and in the meantime, customer loyalty has a negative correlation with the dimensions of excitement and sophistication. Moreover, recent research from Hakkak et al. (2015) about using structural equation modelling techniques shown that customer's intention to use bank services is affected by the brand personality, whereas brand equity can increase this effect by having a positive mediating role. Therefore, such literature reflects this fact that organizations are aware of the importance of relations between brand personality and creating the brand equity and strongly apply it in their brand management strategies. Given that brands can influence on the customers' feeling in their purchase decision-making (Baumgarth, Bill \& Mats, 2011). According to the mentioned literature and the relations among the variables, one can provide the subsequent hypotheses as follows. It should be mentioned that many studies already have examined the relations between research main variables, but there isn't a study examining them as a whole.

H3: Brand personality has a positive and significant effect on brand equity.

H4: Brand personality has a positive and significant effect on customer's purchase intention through brand equity. 


\section{Electronic Word-of-Mouth}

Currently, word-of-mouth (WOM) communication is very important to marketers and is less expensive in comparison to the marketer-initiated communication, and also is more valid for customers. This type of communication is an informal communication between consumers regarding the products or services and it is not similar to the way communication established between consumers and organizations such as complaints or promotions (Polyorat, 2011). Jason, Georgiana and Dongwoo (2010) state the WOM refers to the consumers' interpersonal communication about their personal assessments and experiences encountering a company or product. Nowadays, WOM is widely considered as a powerful effect in the consumer marketplace, especially when consumers are seeking for information and decision.

With the rapid growth of the Internet, the communication has been altered which led to appear as "electronic communication" and considered as a critical phenomenon in marketing. Internet helps the consumers to post their ideas, give comments, review and evaluate products in the blogs, discussion rooms, reviewing websites, newsgroups and social networks. According to Armelini \& Villanueva (2006), increasing use of the internet, especially the social networks among others had paved the way for the exchange of information in the form of "electronic word of mouth" (e-WOM). This information could be negative or positive and could change an organisation's prosperity. Hennig-Thurau, Gwinner, Walsh and Gremler (2004, p. 39) described e-WOM as any positive or negative statement about a product or company from customers which potentially or actually obtained from Internet and is available for many people via the Internet. Following this notion, Duana, Gu and Whinston (2008) define e-WOM as an Internet platform to share the positive or negative reports between the current users and future customers. They also believe that e-WOM is one of the powerful options of sharing information among the customers, since WOM is the procedure of transferring opinions and views from one individual to the other. Finally, Stephanie et al. (2011) reported that e-WOM includes all the informal communications of consumers through internetbased technologies which are defined in relation to the characteristics of specific products or services and their dealers.

It should be noted that WOM plays a big part in the customer purchasing decisions, since provides a channel for consumers to share their perceptions, views or feedbacks about the businesses, goods and services. This argument is affirmed by a research carried out by Nielsen in 2007 in which $78 \%$ of the customers consider into account the recommendation from the e-WOM to make their decisions (Severi, Ling \& Nasermoadeli, 2014). So, increasing significance of e-WOM brings about 
evaluation of consumer's behaviour become necessary and useful for marketing managers and experts. As noted, WOM can be positive or negative which is due to the wide range of sources. In general, it is proved that great extent of information has an effect on consumer behavior (Bickart \& Schindler, 2001). Studies show that e-WOM could be a considerable power to influence on consumer loyalty and purchase intention (Bataineh, 2015; Thomas, Brunner \& Opwis 2006). Different websites have deep effects on consumer purchase decisions by facilitating the way to spread the consumers' views and access to their comments (Zhang, Law \& Li, 2010). Moreover, such advertising has a significant effect on purchase behaviour, consumer communications, and finally on the success of a product in the market. Therefore, positive and negative e-WOM has an effect on consumers' purchase intention (East, Hammond \& Lomax, 2008), and is one of the most efficient elements in impressing brand image and brands purchase intention at consumer markets (Jalilvand et al., 2012).

H5: e-WOM has a positive and significant effect on customer's purchase intention.

Few studies are performed about the e-WOM influence on brand equity which we refer to some of them in the recent years. For example, Thomas et al. (2006) investigated the impact of one special type of e-WOM on customer's perception of value and loyalty intentions and concluded that the customer-to-customer exchange of technical knowledge influences the customer's perception of product value and probability of recommending the product to the others while it does not have any effect on the purchase intentions. Bambauer-Sachse \& Mangold (2011) also show that online reviews of consumer about the product reduce the brand equity. However, recent researches done by Severi et al. (2014) and Eze, Nnabuko and Etuk (2014) indicate a positive relationship between these two constructs. E-WOM will be considered mainly with three goals from company where their implementation lead to keep and enhance the brand equity: 1. Increasing the sale figures of the current products or new products through a low-price tool to attract and maintain the customers; 2. Improving the customer satisfaction indicator; 3. Accessing to the ideas for developing new products by applying the customers' suggestions about new products (Sharma \& Pandey, 2011). The following hypotheses could be offered:

H6: e-WOM has a positive and significant effect on brand equity.

H7: e-WOM has a positive and significant effect on customer's purchase intention through the brand equity. 


\section{METHODOLOGY}

The present study is an applied research in terms of its objectives, it is quantitative in terms of data collection, and it is a descriptive survey in nature. The statistical community of this study consists of the whole customers of Mellat Bank in Qazvin, Iran. The sample size was calculated to be 384 persons by Cochran Formula. To collect the sample, 440 questionnaires were distributed among the customers and 394 questionnaires $(89.5 \%$ is return rate) were collected and analyzed. Since the complete list of customers is not available, convenience sampling which is a nonrandom method has been used in order to achieve the required sample size. Due to the presence of the researcher in the selected branches, and accidental and easy access to the customers in this bank branches, this sampling method is selected.

Mellat bank has 17 branches in Qazvin that initially were divided into clusters. How distribution of bank branches was performed with respect to different geographic area in this cluster are shown in Table 1. Then, we determined the frequency ratio and estimated the number of questionnaires required in each area, those distributed in the chosen branches. After this stage, the researcher went to the branches and distributed the questionnaires among customers of the branch according to the number of questionnaires in each area. Distribution process has been in such a way that the questionnaires are delivered to the customers randomly. However, it can be said that since the list of all customers was not available, random sampling was not applicable and samples have been selected from the available customers. In fact, sampling method was of convenience one. Thus, the opinion of reviewer is correct, and in the research methodology, sampling method has been modified.

Table 1

Number of branches and their frequency ratio in every area

\begin{tabular}{lccc}
\hline Area & Number of branches & Frequency ratio & $\begin{array}{c}\text { The questionnaire Requirements } \\
(\mathrm{n} \times \text { frequency ratio })\end{array}$ \\
\hline North & 1 & 0.06 & 26 \\
East & 2 & 0.12 & 53 \\
West & 3 & 0.17 & 75 \\
South & 9 & 0.53 & 233 \\
Center & 2 & 0.12 & 53 \\
Total & 17 & 1 & 440 \\
\hline
\end{tabular}


Moreover, the research questionnaire consists of two parts, the first part included questions about demographic characteristics of the respondents including gender, age, marital status, education and income. The second part of questions covers the evaluation questions about research constructs, which is designed based on the five-option Likert scale. In second part, Aaker (1996) questionnaire was used to measure the brand personality, Bambauer-Sachse and Mangold (2011) questionnaire to measure e-WOM, Yoo et al. (2000) questionnaire to measure the brand equity and Hakkak et.al. (2015) questionnaire was used to measure the purchase intention.

In order to test the main research model, which is related to the effect of brand personality, e-WOM and CBBE on the purchase intention as well as to estimate the internal effects among these constructs, structural equation model (SEM) can be applied. In comparison to the other statistical procedures, SEM models enable researcher(s) to evaluate the complex models in terms of their compatibility with all the relationships (covariances) in the data set. While SEM is a general term encompassing a variety of statistical models, covariance-based SEM (CBSEM) is a more widely used approach in SEM. CB-SEM is more appropriate to affirm theory testing and confirmation and for this reason, it follows a maximum likelihood (ML) estimation procedure which aims at reproducing the covariance matrix (Astrachan, Patel \& Wanzenried, 2014).

In this way, CB-SEM requires a substantially larger sample size which is recommended to be five times the number of indicators included in the original model (In this research, CB-SEM model has 41 indicator variables in four constructs and the sample size is estimated as $205(41 * 5)$. Thus, to use a sample of 384 customers of Mellat Bank, this research applies CB-SEM to analyse the data. This research also defines the exact number of dependent and independent variables used in the theoretical model, the relationships between these latent variables, and the number of indicator variables are required to ensure a valid and reliable measure of all constructs (these are assumptions for CB-SEM). Moreover, the applicability of the overall measurement models as well as the strength and significance of the relationships (or paths) between the dependent and independent variables by this method are evaluated. CB-SEM in this research is performed by AMOS 18 software and estimation was done using the ML estimation. In AMOS, to determine the suitability of the measuring indicators for measuring latent variables, all observed variables required to be tested separately (Confirmatory factor analysis (CFA) (Tinsley \& Brown, 2000). In this research, latent variables are including the brand personality, e-WOM, CBBE and purchase intention which are measured by the observed variables including all dimensions and questions 
provided in questionnaires. After ensuring the normal distribution of the data, the fitness of fit test was performed for the measurement models and its general indices are given in the following as well as the analytic results of validity, reliability and measurement specification.

To assess the reliability of the research instrument, Cronbach's Alpha method, and to assess the validity, the content and construct validity methods were used. The content validity was approved by the viewpoints of experts and university professors. To determine the validity of the convergent and divergent construct, the correlation coefficients $(\mathrm{R})$, the determination coefficients $\left(\mathrm{R}^{2}\right)$, and the total variance extracted (TVE) of the latent variables were used. The significance of correlations among variables confirms the convergent validity, and the critical value of TVE higher than the $\mathrm{R}^{2}$ of variables confirms the divergent validity. The results of these analyses are presented in Table 2.

Table 2

The research instrument reliability and validity

\begin{tabular}{|c|c|c|c|c|c|c|c|}
\hline Variable & $\begin{array}{c}\text { Brand } \\
\text { Personality }\end{array}$ & $\begin{array}{l}\text { e-Word of } \\
\text { Mouth }\end{array}$ & $\begin{array}{l}\text { Brand } \\
\text { Equity }\end{array}$ & $\begin{array}{l}\text { Purchase } \\
\text { Intention }\end{array}$ & Questions & AVE & Alfa \\
\hline Brand Personality & 1 & - & $\begin{array}{c}0.606^{* *} \\
\mathrm{R}^{2}=0.37\end{array}$ & $\begin{array}{c}0.702^{* *} \\
\mathrm{R}^{2}=0.49\end{array}$ & 15 & 0.50 & 0.83 \\
\hline Word of Mouth & - & 1 & $\begin{array}{c}0.530^{* *} \\
\mathrm{R}^{2}=0.28\end{array}$ & $\begin{array}{c}0.615^{* *} \\
\mathrm{R}^{2}=0.38\end{array}$ & 6 & 0.45 & 0.73 \\
\hline Brand Equity & $\begin{array}{c}0.606^{* *} \\
\mathrm{R}^{2}=0.37\end{array}$ & $\begin{array}{c}0.530^{* *} \\
\mathrm{R}^{2}=0.28\end{array}$ & 1 & $\begin{array}{c}0.702^{* *} \\
\mathrm{R}^{2}=0.49\end{array}$ & 15 & 0.62 & 0.87 \\
\hline Purchase Intention & $\begin{array}{c}0.702^{* *} \\
\mathrm{R}^{2}=0.49\end{array}$ & $\begin{array}{c}0.615^{* *} \\
\mathrm{R}^{2}=0.38\end{array}$ & $\begin{array}{c}0.702^{* *} \\
\mathrm{R}^{2}=0.49\end{array}$ & 1 & 5 & 0.63 & 0.82 \\
\hline
\end{tabular}

Notes: All correlations of between the latent variables at level 0.05 are significant.

As the results show, significance of correlations indicates that convergent validity is confirmed. Moreover, alpha coefficients of higher than 0.7, and AVE values which are greater than 0.5 and $\mathrm{AVE}>\mathrm{R}^{2}$ indicated that the research instrument is reliable and valid. In addition, KMO values were extracted by the heuristic factor analysis on the research variables. Since all values were more than 0.7 , the data are appropriate for the confirmatory factor analysis. Therefore, it can be concluded that the items measured the variables of observation correctly (Tinsley \& Brown, 2000). Based on the data collected from the questionnaire, the frequency of subjects based on demographic variables was evaluated that results have been presented in Table 3 . 
Table 3

Demographic characteristic of respondents

\begin{tabular}{llcc}
\hline Characteristics & & Frequency & $\%$ \\
\hline Gender & Male & 248 & 62.9 \\
& Female & 146 & 37.1 \\
Age Group & Less than 20 years & 48 & 12.2 \\
& 21-30 years & 188 & 47.7 \\
& 31-40 years & 115 & 29.2 \\
& 41-50 years & 26 & 6.6 \\
Marital status & More than 51 years & 17 & 4.3 \\
& Married & 204 & 51.8 \\
Education & Single & 190 & 48.2 \\
& High School & 28 & 7.1 \\
& Diploma & 103 & 26.1 \\
& Associate & 77 & 19.5 \\
Tncome & Bachelor & 141 & 35.8 \\
& Master or higher & 45 & 11.4 \\
& Less than 2 million IRR & 18 & 4.6 \\
& 2-4 million IRR & 108 & 27.4 \\
& 4-7 million IRR & 170 & 43.1 \\
& 7-10 million IRR & 64 & 16.2 \\
& More than 10 million IRR & 34 & 8.6 \\
\hline \multirow{5}{*}{ Total } & 394 & 100 \\
\hline & & &
\end{tabular}

After the data collection, in order to determine that to what extent the measured items are acceptable for measuring the latent variables, confirmatory factor analysis was used. In order to patterns fit, used the absolute and incremental measures fit index. Absolute measures are the most fundamental assessment of the conformity of research proposed model with data collected from the sample and including indices of chi-square (CMIN) and root mean square error of approximation (RMSEA). Likewise, incremental measures compare the estimated model with null model and including indices of normed fit index (NFI), goodness of fit index (GLI) and comparative fit index (CFI). If introduced indices levels be desirable rather than their decision's criteria, can be approved models fit and alignment questions with factors (Tinsley \& Brown, 2000). The results of cconfirmatory factor analysis can be seen in Table 4 . 
Table 4

Confirmatory factor analysis of model's measurement patterns

\begin{tabular}{|c|c|c|c|c|c|c|}
\hline Model Index & CMIN & $\mathrm{CMIN/DF}$ & GFI & CFI & NFI & RMSEA \\
\hline Brand Personality & 6.455 & 1.191 & 0.993 & 0.998 & 0.990 & 0.027 \\
\hline Word of Mouth & 20.552 & 2.284 & 0.984 & 0.976 & 0.959 & 0.057 \\
\hline Brand Equity & 3.528 & 1.764 & 0.995 & 0.998 & 0.995 & 0.044 \\
\hline Purchase Intention & 4.948 & 1.649 & 0.910 & 0.912 & 0.908 & 0.011 \\
\hline Decision criteria & $\mathrm{P}>0.05$ & $1<\mathrm{CMIN} / \mathrm{DF}<5$ & GFI $>0.9$ & $\mathrm{CFI}>0.9$ & $\mathrm{NFI}>0.9$ & RMSEA $<0.1$ \\
\hline
\end{tabular}

Notes: GFI = Goodness of Fit Index, RMSEA = Root Mean Square Error of Approximation, CFI = Comparative Fit Index, NFI = Normed Fit Index.

According to the results in Table 4, it can be said that the smaller the chi square (CMIN), then model developed by the researcher is more satisfactory. If P-value is higher than 0.05 , it indicates that CMIN value is acceptable for model. CMIN/ DF index also shows the differences between the conceptual model and research data; and the smaller level of it (1-5) shows a small difference between conceptual model and research data. Moreover, CFI, GFI and NFI indexes are in a range between zero and one and the more those values are closer to one, the better the model or pattern fits. As the results show, the values of the indices are greater than 0.9 , which indicates a suitable fit for measurement patterns. In addition, RMSEA index which is defined as a different extent for each degree of freedom (df), the more its value is less than 0.08 , the more fit is the model. Therefore, it is observed that models are reached to a favourable level of fit and accordingly, the structure of each variables could be confirmed.

Table 5

Path coefficients and critical values of the research hypotheses

\begin{tabular}{|c|c|c|c|c|c|c|}
\hline \multirow{2}{*}{ Hypothesized Path } & \multicolumn{3}{|c|}{ Path Standard Coefficients } & \multirow{2}{*}{ t-value } & \multirow{2}{*}{ Sig } & \multirow{2}{*}{ Result } \\
\hline & Direct & Indirect & Total & & & \\
\hline$\longrightarrow \mathrm{PI}$ & 0.46 & - & 0.46 & 6.78 & 0.001 & supported \\
\hline $\mathrm{H}_{2}: \mathrm{BE} \longrightarrow \mathrm{PI}$ & 0.52 & - & 0.52 & 7.73 & 0.001 & supported \\
\hline $\mathrm{H}_{3}: \mathrm{BP}$ & 0.75 & - & 0.75 & 11.01 & 0.001 & supported \\
\hline $\mathrm{H}_{4:} \mathrm{BP} \longrightarrow \mathrm{BE} \longrightarrow \mathrm{PI}$ & 0.46 & 0.39 & 0.85 & - & 0.011 & supported \\
\hline $\mathrm{H}_{5}: \mathrm{eWOM}$ & 0.55 & - & 0.55 & 8.12 & 0.001 & supported \\
\hline $\mathrm{H}_{6}: \mathrm{eWOM} \longrightarrow \mathrm{BE}$ & 0.45 & - & 0.45 & 6.31 & 0.001 & supported \\
\hline $\mathrm{H}_{7}: \mathrm{eWOM} \longrightarrow \mathrm{BE} \longrightarrow \mathrm{PI}$ & 0.55 & 0.23 & 0.78 & - & 0.032 & supported \\
\hline
\end{tabular}

Note: $\mathrm{BP}=$ Brand Personality, $\mathrm{BE}=$ Brand Equity, $\mathrm{PI}=$ Purchase Intention, $\mathrm{WOM}=$ Word-of-Mouth. 
After examining fitness of the measurement model in confirmatory factor analysis, we deal with analysing the structural model, fit method and its adaptation as well as the significance tests for each parameter in structural equation models using $\mathrm{t}$-value (CR) index. Table 5 summarises the hypotheses tests based on the CB-SEM analysis and shows the path standardised coefficients and significance between the research structures.

One of the aims of this study is to determine the effect of factors such as brand personality, brand equity and electronic word of mouth on customers' intention to use the banking services and facilities which are measured by seven hypotheses. In relation to the effect of brand personality on customer purchase intention in the first hypothesis (H1), it is revealed that the brand personality has a positive and significant effect on Bank's consumer consumption intentions with 0.46 coefficient ( $\mathrm{t}$-value $=6.78, \mathrm{p}<0.05$ ). This coefficient indicates that for every one-percent increase in the brand personality variable, the customers' intention to use a bank increases to $46 \%$. So, the first hypothesis (H1) at confidence level of $95 \%$ is confirmed and fulfills the research first aim. In order to achieve the research second aim and to determine the effect of brand equity on the customers' intentions to use banking services, the second hypothesis (H2) was presented and the results showed that at confidence intervals of $95 \%$, brand equity can have a positive and significant effect on customer purchase intention of Mellat Bank with a $52 \%$ (t-value $=7.73, \mathrm{p}<0.05)$. In the third hypothesis $(\mathrm{H} 3)$, results showed that the bank's brand personality has a positive and significant effect on brand equity $(\mathrm{t}$-value $=11.01, \mathrm{p}<0.05)$. The value of this effect at the confidence intervals of $95 \%$ is $75 \%$. In other words, in the customers view, strong brand personality for banks can create a positive image of brand and added brand equity. Therefore, confirming this hypothesis allows to achieve the third aim of research.

In order to achieve the fourth aim of study, the result of structural equation modeling techniques in testing the fourth hypothesis (H4) indicated that Mellat Bank's brand personality has both direct and indirect effects on the customers' intention to use banking services. Coefficients value are $46 \%$ and $39 \%$ respectively, which show total effect of brand personality on customer's purchase intention despite the mediator's variable of brand equity that plays a positive mediating role accounting $85 \%(0.46+0.39)$. Therefore, hypothesis $\mathrm{H} 4$ is confirmed at confidence interval of $95 \%(\mathrm{p}<0.05)$. At the same time, in the seventh research hypothesis test $(\mathrm{H} 7)$, it is also observed that the brand equity has a positive mediating role for WOM and can increase the effect of this factor on the customer's purchase intention. Direct and indirect coefficients of this hypothesis are 55\% and 23\% respectively 
which is confirmed at the significance level of $5 \%$. Hence, one of the main aims of this study - revealing the mediating role of brand equity for brand personality and WOM in achieving to customer's purchase intention-was evaluated and approved.

Moreover, one of the research aims was to determine the effect of e-WOM on brand equity and customer intention to use services and facilities of the Mellat bank which were tested in the fifth (H5) and sixth (H6) hypotheses. The results showed that e-WOM with confidence level of $45 \%$ and $55 \%$ respectively, influence on brand equity and bank customer's purchase intention. These coefficients are confirmed at the confidence intervals of $95 \%$ ( $\mathrm{t}$-value $(\mathrm{BE})=6.31$, $\mathrm{t}$-value $(\mathrm{EW})=8.12, \mathrm{p}<0.05)$. These values show that for every one percent increase in e-WOM, brand equity of the bank and its customers' purchase intention increase $45 \%$ and $55 \%$ respectively. Thus, testing each of the hypotheses and analysing their results, research aims are achieved one after the other. According to the hypothesis testing, the output of Amos software is provided in Figure 1.

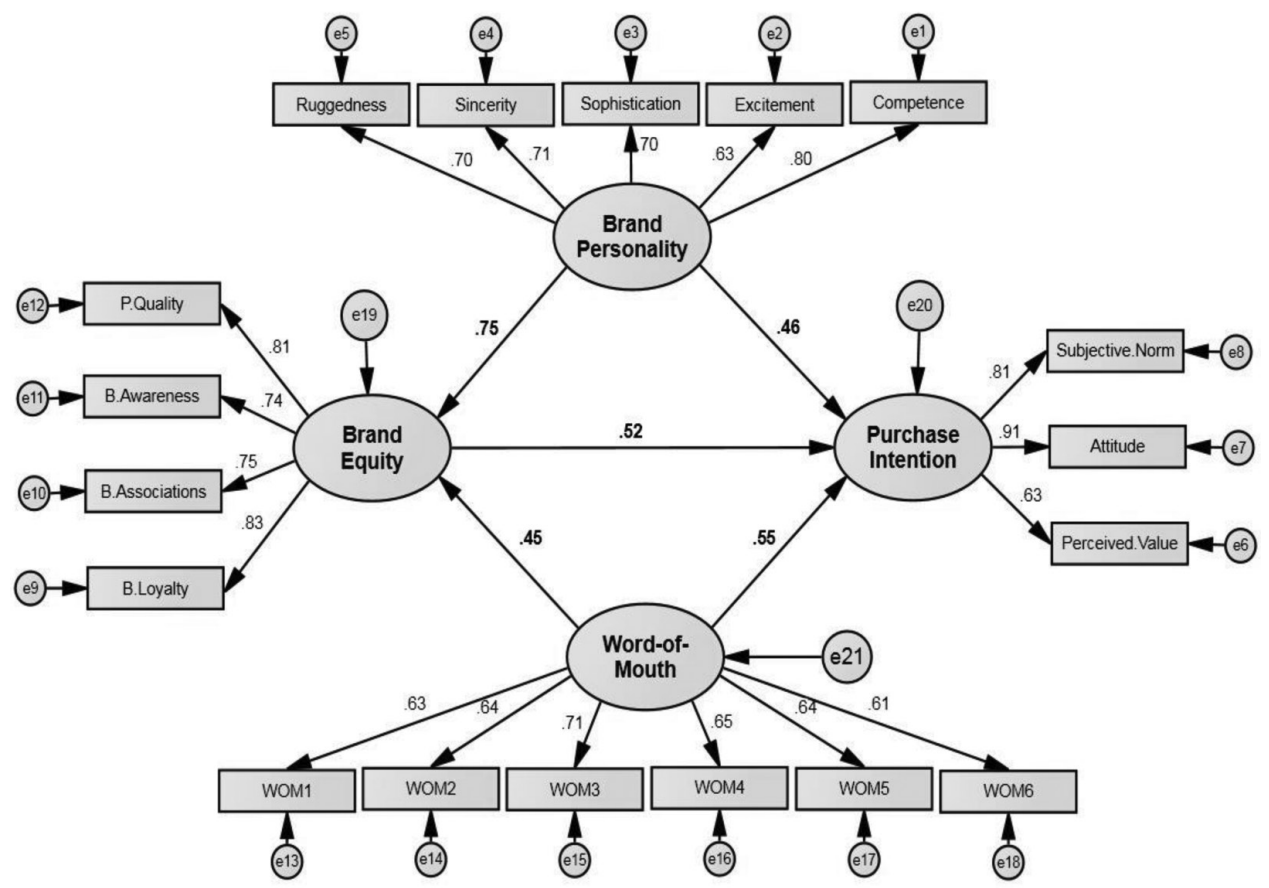

$\mathrm{CMIN}=229.731, \mathrm{DF}=130, \mathrm{GFI}=.937, \mathrm{CFI}=.968, \mathrm{NFI}=.929, \mathrm{RMSEA}=.044$

Figure 1. The research practical model 
As the results of structural model fit in CB-SEM show, the above indices have a high fit and the practical model of the research has an appropriate meaningful structure (Tinsley \& Brown, 2000). Regarding the factor loadings, it is observed that loading factor of the most items for each structure is more than 0.6 which showed a favourable status of the obvious variables and also indicates that the convergent validity is satisfactory. In addition to the hypotheses test in the present study, the levels of each variable were measured using the mean comparison test based on data collected from of Mellat Bank customers. Since, variables levels were higher than 3 (P-value $<0.05)$, it can be concluded the variables are at appropriate levels.

Present study seeks to encourage more customers to use Mellat bank's services and facilities, which led to define several objectives in this regard. One of the research objectives was to determine the effect of brand personality of bank on customers' purchase intention. In fact, one of the new topics in the brand literature in recent years is attributing the human characteristics to brands which is considered as brand personality. In this regard, according to the results of first hypothesis testing, Mellat Bank brand personality has a positive effect on the customers' purchase intentions; it means that positive brand personality of product leads to the increase of customers purchase intention. These results are in accordance with the results of the other studies in this field (Bouhlel et al., 2011; Akin, 2011; Toldos-Romero \& Orozco-Gómez, 2015). According to the results of Figure 1, of the effective dimensions of brand personality on Mellat bank customers' purchase intention, competence and sincerity have the highest factor loading. This means that customers of this bank trust in the brand, consider it as a successful brand and emotionally has a close link to the brand. Hence, Mellat bank with more investment on these dimensions could obtain more distinction in the minds of customers.Besides, this study seeks to examine the effect of brand equity on customers' purchase intention of Mellat bank which its positive effect is approved in the second hypothesis. This means that if the bank's brand has a high equity, it can enhance the consumers' intention to use their facilities and will finally lead to use the facilities and services. The results of this test is in line with the results of Chang and Liu (2009) and Irshad (2012) researches. As the results in Figure 1 shows, among the effective dimensions of brand equity on the purchase intention, brand loyalty is reported as the most important component of brand equity, which is indicative of the loyalty of the majority of customers to Mellat Bank brand than other brands, and they probably would choose this specific brand when they need banking services.

In addition, the findings showed that brand personality has a positive and significant effect on the brand equity. Burke (1994), also declared that one of the benefits of using brand personality is creating the brand equity. This result is consistent with the results of other studies (Irshad, 2012; Gonçalves Santos, 2013). One can say 
that brand personality is one of the essential elements of brand image which can create a desirable and unique set of links in the customers' minds and it can improve the brand equity by creating a unique brand personality. Moreover, one of the research aims was investigating the mediating role of brand equity. The research results showed that navigator factors of purchase intention have domestic impact on each other. In fact, brand personality has a positive and significant effect on brand equity that points out the direct and indirect effect on the customers purchase intention. This means that brand equity has a positive mediating role which can improve the brand personality effect on the customers purchase intention. This result is in parallel with the findings of Hakkak et al. (2015) study. Therefore, developing a positive brand personality based on the customer's minds can increase the customers' intention to use the brand and finally achieve a strong predictor of customer's behaviour. Moreover, the bank's brand equity has a positive mediating role in the relationship between e-WOM and purchase intention which was examined in the seventh hypothesis. Regarding brand equity as a mediator variable in the relationship between e-WOM and purchase intention can improve the effects of this variable on purchase intentions. Indeed, customers' online recommendations and offers to the brand make a positive imaginary of the brand, and increase trust and loyalty for customers which this behaviour in turn, can improve the customers' attitude and intention to use the brand.

In the end, the results revealed that e-WOM has a positive and significant effect on the purchase intention of bank customers. This result reflects a positive WOM can increase the consumer intentions to select and purchase a brand which is in accordance to the findings of Zhang et al. (2010), Bataineh (2015) and Jalilvand et al. (2012). As Table 4 results, e-WOM also has an effect on brand equity at the confidence level of $95 \%$. This result is consistent to the findings of Bambauer and Mangold (2011), and Thomas et al. (2006). Bambauer and Mangold (2011) explained that consumer's negative online reviews about the product undermine the brand equity. In addition, Thomas et al. (2006) found that technical knowledge exchange of customer-to-customer influence on the customer's perception of product value and influence on the possibility of recommending the product to others. Therefore, it can be seen that the results of hypotheses testing led to achieve the research aims.

\section{MANAGEMENT IMPLICATION}

From a practical standpoint, the findings offer important implications for the development of customer purchase intention. According to the results of hypotheses testing, it is suggested to bank managers to strengthen different aspects of their 
brand personality due to the customers' geographical region and culture and based on the five personality characteristics. Because consumers choose the brands that are closest to their characters. Therefore, emphasizing on brand personality characteristics as one of the main components of the study could be a mechanism for differentiation and increases trust among the customers and increase the likelihood of purchasing the brand where it is difficult to choose between brands. Managers who focusing on the five dimensions of brand personality especially the competence and sincerity which have the most loading factor will achieve a perfect brand personality. This can be achieved by raising the level of trust and confidence in brand, representing it as a successful and sincere brand, being useful and beneficial in a variety of fields, and finally use of brand as an emotional and dynamic brand. Creating a competent and sincere brand personality can increase the brand equity and customer intentions to use the services or products.

In addition, brand personality can be formed through variety ways such as marketing communications, sales promotions and social responsibility. Therefore, it is recommended to managers to develop effective and efficient methods of communication and public relations to achieve an appropriate brand personality. Because the creation of proper and strong brand personality can increase the customers' purchase intentions which will lead to business improvement. Moreover, managers should consider the brand personality resources to build a positive character of brand, make a differentiation in comparison to the other brands in the customers' minds and being impressive in dimensions of brand equity. Since one of the immediate resources of brand personality is staff and managers, so personality traits, physical appearance, social and professional behaviour in relation to the customers should be considered along with the brand personality and collectively must be presented to the customers and market to receive a positive assessment by the customers and improve the brand equity.

Furthermore, brand loyalty is the most important dimension in brand equity which can establish an appropriate brand equity in the customer's minds. Therefore, it is proposed to managers to do a wide range of activities to ensure applying the quality standards in providing services and products, and also extensive advertising about the product. Because, it can have dramatic results in creating customer loyalty by creating a favorable memory image of product. Moreover, they should endeavor to increase and keep customer loyalty by increasing the customer awareness of their brand. After the brand loyalty, the dimensions of perceived quality, brand association and brand awareness require special attention by managers, respectively. Also, focusing on customer-based brand equity can increase the brand personality and e-WOM effects on the customer purchase intention which this effect is greater than the direct effect. In fact, focusing on the five dimensions of 
brand personality and e-WOM will improve the brand equity, which it in turn leads to further increased customer purchase intention. Therefore, marketing managers can develop customers purchase intention especially their attitude and subjective norms indirectly.

Likewise, it is suggested to bank managers to launch websites for consumers and advertise by applying ways such as comments, emails in the target website as well as using ideas of the popular managers and leaders and conduct the flow of e-WOM. This action lead to increase in attracting customers and their purchase intention. Finally, it is recommended to improve the bank brand equity and increase the use of facilities, managers should do actions like publishing the informative WOM advertisements for brand in credit online channels, giving WOM advertising messages in which the perceived high quality of the customers about the products and services are reflected. Moreover, using the loyal customers for publishing WOM and viral advertisement will improve the brand equity which is followed by increasing the purchase intention.

\section{RESEARCH LIMITATIONS AND SUGGESTIONS FOR FUTURE RESEARCH}

Research data were collected using a cross-sectional, so the variables and results possibly are limited to a period of time. In addition, the area covered by this study is limited to Mellat bank, it is probable that the results could not be generalised to the other banks, because the challenges and factors affecting customers' intention in using services and facilities may vary in other banks. Hence, the study community could be expanded in the future studies in order to obtain more accurate results. Moreover, it is suggested to the future researchers to measure the present research model for other brands to be able to compare their results, and determine the differences. Also, it is advised that they consider the effect of brand personality, e-WOM and brand equity using the brand personality of Geuens, Weijters and De Wulf (2009), focusing on the resources of electronic word of mouth and finally considering the financial and corporate approaches to brand equity in other variables such as the brand performance, brand recall, brand relationship, consumer perceptions etc.

\section{ACKNOWLEDGEMENT}

Last but not the least I place a deep sense of gratitude to my friends "Mohammad Sadegh Jafari and Javad Taheri Moghaddam" who have been constant source of inspiration during the preparation of this project work. 


\section{REFERENCES}

Aaker, D. (1991). Managing brand equity: Capitalizing on the value of a brand name. New York: The Free Press.

Aaker, D. (1996). Measuring brand equity across products and markets. California Management Review, 38(3), 102-120. https://doi.org/10.2307/41165845

Aaker, J. (1997). Dimensions of brand personality. Journal of Marketing Research, 34(3), 347-356. https://doi.org/10.2307/3151897

Aggarwal, P. (2004). The effects of brand relationship norms on consumer attitudes and behavior. Journal of Consumer Research, 31(1), 87-101. https://doi.org/ $10.1086 / 383426$

Ainscough, T. L., Trocchia, P. J., \& Gum, J. R. (2009). Consumer rental car choice: Price, agent, and brand effects. Journal of Business and Economics Research, 7(7), 39-48.

Akin, M. (2011). Predicting consumers' behavioral intentions with perceptions of brand personality: A study in cell phone markets. International Journal of Business and Management, 6(6), 193-206. https://doi.org/10.5539/ijbm.v6n6p193

Alsughayir, A., \& Albarq, A. N. (2013). Examining a theory of reasoned action (TRA) in internet banking using SEM among Saudi consumer. International Journal of Marketing Practices, 1(1), 16-30.

Armelini, G., \& Villanueva, J. (2006). what do we know about this Electronic word of mouth powerful marketing tool. E-Business Center PricewaterhouseCoopers \& IESE, 11(2), 38-47.

Astrachan, C. B., Patel, V. K., \& Wanzenried, G. (2014). A comparative study of CB-SEM and PLS-SEM for theory development in family firm research. Journal of Family Business Strategy, 5, 116-128. https://doi.org/10.1016/j.jfbs.2013.12.002

Atilgan, E., Aksoy, S., \& Akinci, S. (2007). Determinants of the brand equity. Marketing Intelligence and Planning, 23(3), 237-248. https://doi.org/10.1108/ 02634500510597283

Azoulay, A., \& Kapferer, J. N. (2003). Do brand personality scales really measure brand personality?. Journal of Brand Management, 11(2), 143-155. https://doi.org/ 10.1057/palgrave.bm.2540162

Baker, T. L., Hunt, J. B., \& Scribner, L. L. (2002). The effect of introducing a new brand on consumer perceptions of current: The roles of product knowledge and involvement. Journal of Marketing Theory and Practice, 13, 34-45. https://doi.or $\mathrm{g} / 10.1080 / 10696679.2002 .11501925$

Bambauer-Sachse, S., \& Mangold, S. (2011). Brand equity dilution through online wordof-mouth communication. Journal of Retailing and Consumer Services, 18(1), 38-45. https://doi.org/10.1016/j.jretconser.2010.09.003

Bataineh, A. Q. (2015). The impact of perceived e-WOM on purchase intention: The mediating role of corporate image. International Journal of Marketing Studies, 7(1), 126. https://doi.org/10.5539/ijms.v7n1p126

Baumgarth, C., Bill, M., \& Mats, U. (2011). Brand orientation and market orientation. Journal of business research, 66, 13-20. 
Beadnell, B., Baker, S. A., Gillmore, M. R., Morrison, D. M., Huang, B., \& Stielstra, S. (2008). The theory of reasoned action and the role of external factors on heterosexual men's monogamy and condom use1. Journal of Applied Social Psychology, 38(1), 97-134. https://doi.org/10.1111/j.1559-1816.2008.00298.x

Bertoncelj, A., \& Moisescu, O. I. (2010). A comparative study of the relationship between brand loyalty and market share among durable and non-durable products. Management \& Marketing-Craiova, (1), 137-145.

Bickart, B., \& Schindler, R. M. (2001). Internet forums as influential sources of consumer information. Journal of Interact Market, 15(3), 31-40. https://doi.org/10.1002/ dir. 1014

Botha, N., \& Atkins, K. (2005). An assessment of five different theoretical frameworks to study the uptake of innovations. New Zealand Agricultural and Resource Economics Society, NZARES Conference.

Bouhlel, O., Mzoughi, N., Hadiji, D., \& Ben Slimane, I. (2011). Brand personality's influence on the purchase intention: A mobile marketing case. International Journal of Business and Management, 6(9), 210-227. https://oi.org/10.5539/ ijbm.v6n9p210

Braunstein, J. R., \& Ross, S. D. (2010). Brand personality in sport: Dimension analysis and general scale development. Sport Marketing Quarterly, 19(1), 8.

Bruwer, J., \& Buller, C. (2005). Country-of-origin brand preferences and associated knowledge levels of Japanese wine consumers. Journal of Product and Brand Management, 25(1), 307-316.

Burke, B. (1994). Position, personality, not price, should frame consumer messages. Brandweek, 35, 36-65.

Chang, H. H., \& Liu, Y. M. (2009). The impact of brand equity on brand preference and purchase intentions in the service industries. The Service Industries Journal, 29(12), 1687-1706. https://doi.org/10.1080/02642060902793557

Chi, H., Yeh, H. R., \& Tsai, Y. C. (2011). The influences of perceived value on consumer purchase intention: the moderating effect of advertising endorser. Journal of International Management Studies, 6(1), 1-6.

Chung, J. E., \& Pysarchik, D. (2000). A model of behavioral intention to buy domestic versus imported products in a Confucian culture. Marketing Intelligence and Planning, 18(5), 281-291. https://doi.org/10.1108/02634500010343982

Collen, H., \& Hoekstra, J. (2001). Values as determinants of preferences for housing attributes. Journal of Housing and the Built Environment, 16(3-4), 285-306. https://doi.org/10.1023/A:1012587323814

Crosno, J. 1., Freling, T. H., \& Skinner, S. J. (2009). Does brand social power mean market might? Exploring the influence of brand social power on brand evaluation, Psychology and Marketing, 26, 91-121. https://doi.org/10.1002/mar.20263

Dodds, W., Monroe, K., \& Grewal, D. (1991). Effects of price, brand, and store information on buyers' product evaluation. Journal of Marketing Research, 28, 307-319. https://doi.org/10.2307/3172866

Duana, W., Gu, B., \& Whinston, A. (2008). Do online review matter? An empirical investigation of panel data. Journal of Decision Support System, 45(4). https://doi.org/10.1016/j.dss.2008.04.001 
East, R. Hammond, K., \& Lomax, W. (2008). Measuring the impact of positive and negative word of mouth on brand purchase probability, Intern. Journal of Research in Marketing, 25, 215-224. https://doi.org/10.1016/j.ijresmar.2008.04.001

Eze, J. F., Nnabuko, J., \& Etuk, A. (2014). An evaluation of e-word-of-mouth communication on brand equity in Cross River State, Nigeria. International Journal of Development and Sustainability, 3(9), 1814-1821.

Fishbein, M., \& Ajzen, I. (1975). Belief, attitude, intention and behavior: An introduction to theory and research: Reading. MA: Addison-Wesley.

Geuens, M., Weijters, B., \& De Wulf, K. (2009). A new measure of brand personality. International Journal of Research in Marketing, 26(2), 97-107. https://doi.org/ 10.1016/j.ijresmar.2008.12.002

Gonçalves Santos, M. R. (2013). Axe's brand personality and equity, consumers' perspectives on the brand's personality and equity. MSc Dissertation in Business Administration, Universidade Católica Portuguesa.

Hakkak, M., Vahdati, H., \& Mousavi Nejad, S. H. (2015). Study the role of customer-based brand equity in the brand personality effect on purchase intention. International Journal of Asian Social Science, 5(7), 369-381. https://doi.org/10.18488/journal.1/ 2015.5.7/1.7.369.381

Hennig-Thurau, T., Gwinner, K. P., Walsh, G., \& Gremler, D. D. (2004). Electronic word-of-mouth via consumer-opinion platforms: What motivates consumers to articulate themselves on the Internet?. Journal of Interactive Marketing, 18(1), 38-52. https://doi.org/10.1002/dir.10073

Irshad, W. (2012). Service based brand equity, measure of purchase intention, mediating role of brand performance. Academy of Contemporary Research Journal, 1(1), $1-10$.

Jalilvand, M., Samiei, N., \& Mahdavinia, S. H. (2012). The Effect of electronic word of mouth on brand image and purchase intention: An empirical study in the automobile industry in Iran. Journal of Marketing Intelligence and Planning, 30(4), 5-5. https://doi.org/10.1108/02634501211231946

Jason, Q. Z., Georgiana, C., \& Dongwoo, S. (2010). When does electronic word-of-mouth matter? A study of consumer product reviews. Journal of Business Research, 63, 1336-1341. https://doi.org/10.1016/j.jbusres.2009.12.011

Jung, J., \& Sung, E. Y. (2008). Consumer-based brand equity: Comparisons among Americans and South Koreans in the USA and South Koreans in Korea. Journal of Fashion Marketing and Management, 12(1), 24-35. https://doi.org/ $10.1108 / 13612020810857925$

Keller, K., \& Lehmann, D. (2004). Brand and branding: research finding and future priorities, international. Journal of Research in Marketing, 1-55.

Keller, K. L. (1993). Conceptualizing, measuring and managing customer-based brand equity. Journal of Marketing Research, 57(1), 1-22. https://doi.org/10.2307/ 1252054

Kim, D. P., Magnini, V., \& Singal, M. (2011). The effects of customers' perceptions of brand personality in casual theme restaurants. International Journal of Hospitality Management, 30(2), 448-458. https://doi.org/10.1016/j.ijhm.2010.09.008 
Kim, E. Y. \& Kim, Y. K. (2004). Predicting online purchase intentions for clothing products. European Journal of Marketing, 38(7), 883-897. https://oi.org/ $10.1108 / 03090560410539302$

Lemon, K. N., Rust, R. T., \& Zeithaml, V. A. (2001). What drives customer equity. Marketing Management, 10(1), 20-25.

Mengxia, Z. (2007). Impact of brand personality on PALI: a comparative research between two different brands. International Management Review, 3(3), 36-46.

Park, C., \& Lee, T. M. (2009). Information direction, website reputation and eWOM effect: A moderating role of product type. Journal of Business Research, 62(1), 61-67. https://doi.org/10.1016/j.jbusres.2007.11.017

Polyorat, K. (2011). The influence of brand personality dimensions on brand identification and word-of-mouth: The case study of a university brand in Thailand. Asian Journal of Business Research, 1(1), 54-69. https://doi.org/10.14707/ajbr.110004

Rekom, J., Jacobs, G., \& Verlegh, P. (2006). Measuring and managing the essence of a brand personality. Marketing Letters, 17, 181-192. https://doi.org/10.1007/s11002006-5362-5

Severi, E., Ling, K. C. \& Nasermoadeli, A. (2014). The impacts of electronic word of mouth on brand equity in the context of social media. International Journal of Business and Management, 9(8), 84-96. https://doi.org/10.5539/ijbm.v9n8p84

Shahrokh, Z. D., \& Azodi, A. D. (2013). The effect of country of origin image on brand equity and purchase intention. Journal of Applied Environmental and Biological Sciences, 3(12), 52-61.

Sharma, R. S., \& Pandey, T. (2011). The impact of electronic word-of-mouth in the distribution of digital goods. Webology, $8(1)$.

Stephanie, H., Aaron, G., Lay Peng, T., \& Jayne, K. (2011). The effect of brand personality and congruity on customer-based brand equity and loyalty of personal computer brands. Proceedings of the Academy of Marketing Conference: Marketing Field Forever, Liverpool, Academy of Marketing.

Temporal P. (2000). Branding in Asia. The creation, development and management of Asian Brands for the global Market. New York: John Wiley \& Sons Inc.

Teng, L., Laroche, M., \& Zhu, H. (2007). The effects of multiple-ads and multiple-brands on consumer attitude and purchase behavior. Journal of Consumer Marketing, 24(1), 27-35. https://doi.org/10.1108/07363760710720966

Thomas, A., Brunner, M., \& Opwis, K. (2006). Satisfaction,image and loyalty: new versus experienced customers. European Journal of Marketing, 42(9/10).

Tinsley, H. E. A., \& Brown, S. D. (2000). Handbook of applied multivariate statistics and mathematical modeling. Academic Press.

Toldos-Romero, M. D. L. P., \& Orozco-Gómez, M. M. (2015). Brand personality and purchase intention. European Business Review, 27(5), 462-476. https://doi.org/ 10.1108/EBR-03-2013-0046

Valette-Florence, P., Guizani, H., \& Merunka, D. (2011). The impact of brand personality and sales promotions on brand equity, Journal of Business Research, 64(1), 24-28. https://doi.org/10.1016/j.jbusres.2009.09.015 
Wang, X., Yang, Z., \& Liu, N. R. (2009). The impacts of brand personality and congruity on purchase intention: Evidence from the Chinese mainland's automobile market. Journal of Global Marketing, 22(3), 199-215. https://doi. org $/ 10.1080 / 08911760902845023$

Yoo, B., Donthu, N., \& Lee, S. (2000). An examination of selected marketing mix elements and brand equity. Journal of the Academy of Marketing Science, 28(2), 195-211. https://doi.org/10.1177/0092070300282002

Zhang, Z., Ye, Q., Law, R., \& Li, Y. (2010). The impact of e-word-of-mouth on the online popularity of restaurants: A comparison of consumer reviews and editor reviews. International Journal of Hospitality Management, 29, 694-670. https://doi.org/ 10.1016/j.ijhm.2010.02.002 